\title{
Literacy Media Development in Improving Reading and Writing Skill of Early Class Students in Elementary School Padang Utara Padang
}

\author{
Elfia Sukma, Ritawati Mahjuddin, Rizky Amelia
}

Padang State University, Padang, Indonesia

e-mail: elfiasukma66@yahoo.com

\begin{abstract}
This research aims to develop literacy media in improving reading and writing skill of early class students in elementary school Padang Utara, Padang. This research uses R\&D approach with 4-D developing model. 4$\mathrm{D}$ model has main phases, those are defina, design, develop, and disseminate. The data were obtained based on the observation result using the observation sheet. Data were analyzed by using qualitative data analysis approach. Research subjects consist of teachers and students of SD Padang Utara, Padang. The results showed that literacy skills (reading and writing) in the early classes has an important role in determining the success of students' learning. Literacy media is proven to increase student's pleasure while reading and writing. This makes students interested in reading material so that it can enhance students' understanding of reading content.
\end{abstract}

Keywords: literacy media, early class.

\section{INTRODUCTION}

Literacy can be comprehended as the skill of understanding the alphabets, lettering, and also the ability to read and write. Literacy is the ability of one's language (listening, speaking, reading, and writing) to communicate in different ways according to its purpose. Sulzby (1986) defines literacy specifically, that literacy as the ability to read and write. This is due to the opinions of Grabe \& Kaplan (1992) and Graff (2006) who interpreted literacy as the ability to read and write.

Literacy is very essential for students because the skill in literacy has a significant influence to the students succeed in learning and their daily life. A good literacy skill will help students in comprehending oral text, written, and even visual texts. Literacy skill (reading and writing) in basic class plays an important role in determining the students learning success. In this stage, learning to read and write need to be introduced. Both of those skills will not develop automatically, but it need to be taught. When the literacy learning (reading and writing) in the early classes is not more intense, then in further reading and writing phase students will experience difficulty to achieve a proper reading and writing skill. Reading and writing abilities is indispensable for people who wants to expand their knowledge and experience, enhance thinking power, sharpen reasoning, to achieve progress and self improvement.

Zuchdi and Budiasih (2001, p.57) revealed that the reading ability obtained at the preliminary reading will greatly affect further ability to read. As the ability that underlying the advanced capability, a preliminary reading skills actually require the teacher's concern. The preliminary reading skill is the primary for further teaching. As a foundation, the skills of reading should be intense and firm. Therefore, preliminary reading activities should be served and implemented seriously and earnestly. Patience and accuracy is needed in training, guiding, and directing students to achieve the expected goals.

The preliminary reading is the stage of the process in learning to read for elementary school students on early class. Students learn to acquire skills and master the reading techniques and comprehend the reading content very well. Therefore, teachers need to design the methods of learning to read appropriately, so that students become interested and accustomed to reading because the awareness of reading improved which is a fun activity. Thus, the teacher take a very important role in fostering students motivation to learn, especially the motivation of learning to read.

Stages of reading for a student is very important because it will affect the attitude of reading and his views on reading materials. A survey conducted by the International Education 
Achievement (IEA) in early 2000 showed that the reading quality of Indonesian children ranked 29th of 31 countries studied in Asia, Africa, Europe and America. This is certainly very desolating condition because reading is an essential thing that students must be interested to support the learning process.

When a student is forced in learning to read and he or she has not learned the basic skills, it can lead to frustration and loss of confidence in reading. Teachers must understand the proper sequence in reading skills so that students will not find it difficult in learning to read. Therefore, students' comprehension of sound is very important.

Students' reading attitudes will have an effect on their writing. While learning how to read, he is also learning how each letter is formed. Similarly with learning to read, the experience of learning to write will also affect the interest of writing later. The reluctance to read may be the result of the unpleasant recognition process of reading at school or at home. Adolescent coercion of a child to read immediately in a short time may adversely affect their interest in reading.

Literacy learning in the early classes requires tools or materials that can assist students in optimizing their reading and writing skills. Characteristics of early class students who have shorter concentration ranges need support so that they have an interest in what they are learning. Literacy media such as drawings, graphs / diagrams or objects of interest can help in optimizing the process of students learning to read and write.

The research revealed that students will understand the concept given more easily through visual or verbal (Salomon, 1979). Meanwhile, Cowen (1984) states that the use of visual media makes students remember more information than just using text media.

Abbas (2006: 126) reveals that in the period of readiness to read and write, students learn to understand that: (a) the writing in the book is composed from left to right (in the Latin writing system); (b) the language consists of words; (c) the words consist of sounds; (d) the sounds are drawn with letters; (e) every letter has its name; And (g) the number of letters is limited.

This research activity is aimed to develop literacy media in imroving the reading and writing skill of first grade students in SD Padang Utara Padang. The development of literacy media is expected to be used in achieving the learning objectives of the Indonesian language contained in the curriculum optimally.

\section{METHODS}

The development model undertaken in this research follows the flow of Sivasailam Thiagarajan, Dorothy S. Semmel, and Melvyn I. Semmel (1974.). The main 4-D development model is define, design, develop, and disseminate or adapted into a 4-P model, defining, designing, developing, and deploying. Implementation of the main step in this research is not only tracing the original version but adapted to the characteristics of the subject and place of origin of examinee. In addition, the model used is customized to the needs of development in the field.

To be more focused, then this research procedure is implemented in 4 stages, which can be shown in the steps chart of the of developing named the fish bone as follows:

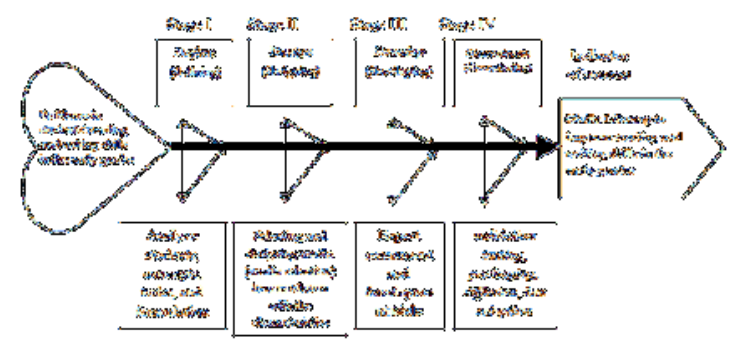

Figure 1. Research Prosedure

\section{RESEARCH RESULTS AND DISCUSSION}

Media literacy is a comprehending process of communication resources and technologies, symbols used, and the process of selection, interpretation, and impact of those messages. Then The National Communication Association in Potter $(2010,677)$, a professional undergraduate organization founded by a large number of university academics stated that media literacy is :

Being a critical and reflective consumer of communication requires an understanding of how words, images, graphics, and sounds work together in ways that are both subtle and profound. Mass media such as radio, television, and film and electronic media such as the telephone, the internet, and computer conferencing influence the ways meanings are created and shared in contemporary society. So great is this impact that in choosing how to send a message and evaluate its effect, communicators need to be aware of the the distinctive characteristic of each medium. 
This professional organization explains that we should be critical and reflective in consuming communication media. This requires an understanding of how words, images, graphics, and sounds "work together" in an elusive and hard finding, and alertness about the different effects of each medium. Media literacy is the result of a dynamic process between basic (availability and context) and peak (communicative ability). The process from base to peak is the competence of individual media (media usage and critical understanding) Celot (2010, 33).

From those definition, media literacy can be translated as a media skill, which is a comprehensive awareness and ability to place themselves and society through media as active actors. With the presence of media skills, one is expected to be able to select the media and its contents for consumption, so media literacy is defined as an understanding of the sources and communication technologies, codes used, the messages produced and the selection, interpretation and impact of the messages. Many pepole blame inappropriate television shows or mention and complain about the harmful effects it poses directly, but rarely question the role of self in the process of mass communication.

\subsection{Reading and Writing in the Early Class}

Anderson (Dhieni, et al., 2008, p.5.5) reveals that the preliminary reading is an integrated reading activity, emphasizing the introduction of letters and words and relating them to sounds. According to Zuchdi and Budiasih (1996: 50) preliminary reading given gradually, namely pre-reading and reading. At the pre-reading stage, students are taught and familiarized to do the following activities: (1) A good sitting posture at the time of reading, (2) How to place a book on a desk, (3) How to hold a book, (3) How to open and turn pages, And (4) View and pay attention to writing.

The preliminary writing ability is not much different from the preliminary reading ability. At a basic level, learning to write is more oriented towards non-mechanical abilities. Students are trained to be able to write (similar to the ability to paint or draw) written symbols when coupled in a structure, the symbols become meaningful. Furthermore, with this basic skill, students are gradually led to the ability to pour ideas, thoughts, feelings, into the form of written language through the written symbols they have mastered. This is the true writing ability. Students must understand that the writing has meaning and represents spoken language. Writing is a medium for expressing ideas, feelings, and conveying messages.
Zuchdi and Budiasih (1996, p.62) stated that writing skill is one kind of a productive writing skill. It means that writing skills are a skill that produces things (in this case produce writing). Abbas (2006, p.126) reveals that in the period of readiness to read and write, students learn to understand that: (a) the writing in the book is composed from left to right (in the Latin writing system); (b) the language consists of words; (c) the words consist of sounds; (d) the sounds are drawn with letters; (e) every letter has its name; And (f) the number of letters is limited.

The learning to read preliminary writing is given to the first grade students of elementary school / madrasah ibtidaiyah. The main purpose of learning to read preliminary writing is that students can recognize writing as a symbol or symbol language, so that students can express the writing. Thus, the main emphasis of the activity is reading or expressing the writing or symbols, and making or producing the writing, even so the meaning read can not be ignored, even the pressure. Writings that are read or expressed and made must remain meaningful. This should be emphasized because the comprehension of a meaning makes it easier to recognize letters. Then, step by step, students are expected to comprehend the meaning that read and write it down the idea or meaning to be conveyed. In addition to these goals, the formation of a positive attitude in reading and writing as well as clean and neat habits in writing also need to be considered. In addition to the above understanding, students should know that writing is the activity of manifesting words in a series of letters on a book page or whiteboard.

\subsection{Media Literacy in the Early Grade 3.2.1 Big Book}

Big Book is a book that has a large size, writing, and pictures. Big Book size can vary, such as A3, A4, A5 size, or the size of a newspaper. The size of the Big Book should concern about the legibility of all students in the class. Big Book can be used in the early class because it has characteristics that suit the needs of students. Teachers can choose Big Book in which content of the story and the topic in accordance with the interests of students or in accordance with the theme of the lesson. In fact, teachers can create their own Big Book according to the characteristics and needs of students.

Big Books are used by teachers when they are modeling reading or writing together. This type of book is kind of interest to students because it attracts their attention. According to Karges-Bone (1992), in order to make language learning to be more effective and successful, a Big Book should have the following features: (1) Short stories (10-15 pages), 
(2) Clear sentence patterns, (3) Images have meaning, (4) The type and size of the letters are clearly legible, and (5) The storyline is easy to understand.

Some Big Book pages bring up the word repeatedly for students to learn. Curtain and Dahlberg (2004) stated that Big Book allows students to learn how to read through the way they remember and repeat the reading. Many educational specialists claim that Big Book is best used in the early classes because it can help increase students' interest in reading. The use of the Big Book in reading learning has several objectives among those are as follow: (a) Provide reading experience, (b) Assist students to understand the book, (c) Introduce different types of reading materials to students, (d) Involve students actively in learning, (e) Provide good text samples for students to use, and (f) Dig information.

With its large size and attractive images, the Big Book has several features, among those are as follows.

a) Provide opportunities for students to engage in reading activities together.

b) Allow all students to see the same writing when the teacher reads the text.

c) Allowing students together in giving meaning to each article in the Big Book.

d) Provide opportunities for students who are slow to read to recognize writing with the help of teachers and other friends.

e) Liked by students, including students who are slow in reading. By reading the Big Book together, there is courage and confidence in students that they "can" read.

f) Develop all aspects of language.

\subsubsection{Stories Calendar}

The story calendar is an arrangement of several sheets of paper containing a neatly arranged message or resource that is created like a calendar. Called the story calendar because it looks like a calendar. Each page can be used for different days. The story calendar is a practical, effective, and efficient literacy media and can be used as a learning tool for students, both inside and outside the classroom. Easy story calendar created by teachers.

There are several things that need to be considered by the teacher, those are:

a. The paper size is very flexible, but it must be ensured it can be used easily by students,

b. The type of paper used is free,

c. Each page contains different tasks as needed, for example the first page is just a story and students are asked to read the story. On the next page, students are asked to draw story characters,

d. Each page has different tasks according to many pages depending on needs, can be 5 or 6 pages; Each page is devoted to student activities for 1 day, it has a book cover with a title customized to the needs.

The use of the story calendar has several purposes, including:

1) Motivate students in reading and writing because each page has a linkage,

2) Facilitate teachers in assessing the development of literacy skills for a certain period of time.

The story calendar is enriched with literacy and interesting to use by early grade students. The specialty of the story calendar is the existence of material that is related to each other and enriched with images that can give space for students to explore and imagine. Apart from easy to carry, the calendar can be used as a portfolio because page by page gives an overview of the development of student literacy.

When developing a story calendar, a teacher should pay attention to the following matters.

a. The number of papers required for The story calendar can be used according to the number of days specified by the teacher. Based on the number of days, the teacher determines the amount of paper needed for each student, including the front page for the title.

b. The purpose of the story calendar. Before creating a story calendar, the teacher must first determine the goal; Whether to practice handwriting, creative writing, or reading comprehension.

c. Theme. The teacher must determine the theme of the story calendar content. For example, animal theme. With the theme, the teacher asks students to develop the content of the story calendar material into 5-6 pages.

d. Images and reading materials that suit the needs of students. Before creating a story calendar, teachers prepare reading materials that are appropriate to the needs of the students.

\subsubsection{Picture Media}

According to the proverb, a picture has thousands of meanings. Through pictures, many messages are delivered. In the literacy class, students can convey many things through pictures. The use of 
picture media is expected to improve reading and writing skills as well as speaking and listening skills.

The picture media includes a silent visual media type in graphical form. Graphics media is defined as a medium that combines facts and ideas in a clear and powerful way through a combination of disclosure of images and words. Another meaning, the pictures media are various events, objects are poured in the form of pictures, photos, diagrams, paintings, lines, symbols, or illustrations.

The picture media is very well used in early class literacy because:

a. Concrete and interesting.

b. It can show / illustrate a situation, realistic / empirical event.

c. It can overcome limitedness because it can bring things, objects, or events that can not be presented into the classroom.

d. Cheap and easy to get.

e. Easy to use and flexible According to R. Lloyd Ryan (1993), the use of picture media is more effective when the teacher notices the following points in the making.

a. The source of pictures can be taken from photos of objects, magazines, calendars, greeting cards, postcards, brochures, posters or big books.

b. Flexible size, adjusted to the number of students and their use. The theme of the image is adjusted to the age, interests, and child world.

c. Each picture can be laminated so that it will be durable.

d. Pictures may be single drawings or series drawings.

The use of picture media in the classroom provides several advantages for both students and teachers. picture image media can work for:

1) Clarify the presentation of messages and information so it can facilitate and improve the process of literacy learning.

2) Improve and direct the students' attention so they can focus on learning.

3) Improve the motivations of learning

4) Give students the experience and ability to perceive an object in the

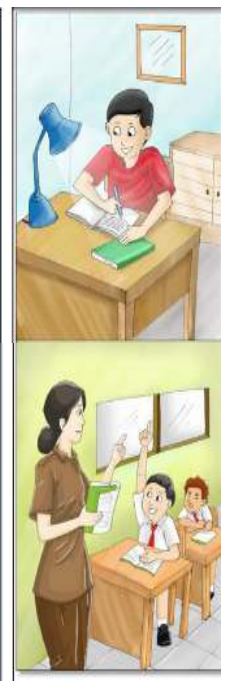

picture, it has the function of attention, affective and cognitive.

5) It has a compensatory function, which helps students who are weak in reading to have capability in organizing information in the form of writing.

\section{CONCLUSIONS AND SUGGESTIONS}

From the result and discussion of the research above, the conclusion that can be drawn from this research is literacy skill (reading and writing) in the early class plays an important role in determining the success of student learning. Literacy media is proven to increase student's pleasure while reading and writing. This makes students interested in reading material so it can enhance students' understanding of reading content.

Literacy skills will not be achieved without conscious and planned effort. Therefore, in order to make students quickly recognize the letters, distinguish between the letters one and the other, and finally get the ability to read, the introduction of literacy should use media that can attract students' attention so as to help them to improve their reading and writing skills. Moreover, the demonstration conducted by the teacher with reading habits also plays an important role, because students understand that the habit is a cultural behavior that should be done. The teacher's habits in reading stories, showing pictures and read the accompanying writings, write down the poems found in the reading, make the students happy, satisfied, and motivated to imitate them later.

Based on the conclusions obtained in this research, the authors suggest to the teachers of primary schools and educational practitioners, that the development of literacy media is expected to be used in achieving the objectives of Indonesian language learning contained in the curriculum optimally.

\section{REFERENCES}

[1] Abbas, Saleh, Pembelajaran Bahasa Indonesia yang Efektif di Sekolah Dasar. Jakarta: Depdiknas, 2006.

[2] Abdurrahman, Mulyono, Pendidikan Bagi Anak Berkesulitan Belajar. Jakarta: Rineka Cipta, 2003. 
[3] Akhadiah, Sabarti, Bahasa Indonesia I. Jakarta: Depdiknas, 1993.

[4] Dhieni, Nurbiana, Metode Pengembangan Bahasa. Jakarta: Universitas Terbuka, 2008.

[5] Grabe, W. \& Kaplan R. (Eds.), Introduction to Applied Linguistics. New York: AddisonWesley Publishing Company, 1992.

[6] Graff, Harvey J, Literacy. Microsoft ${ }^{\circledR}$ Encarta ${ }^{\circledR} \quad$ [DVD]. Redmond, WA: MicrosoftCorporation, 2005.

[7] Mcknight, Katherine S, The Teacher's Big Book of Graphic Organizers. San Francisco: Jossey-Bass, 2010.

[8] Paivio, A. \& Clark, Dual Coding Theory and Education. Educational Psychology Review, 1991.

[9] Ryan, Lylod R, Using Pictures in Teaching Art and Other Stuff. Diunduh dari http://www.mun.ca/educ/faculty/mwatch/vol2/ ryan2.html, Mei 2016.

[10] Supriyadi, Pendidikan Bahasa Indonesia 2. Jakarta: Depdikbud, 1994.

[11] Tarigan, Henry Guntur, Menulis sebagai Suatu Keterampilan Berbahasa. Bandung: Penerbit Angkasa, 1986.

[12] Tompkins, Gaile E, Teching Writing: Balancing Process and Product. New York: Macmilan College Publishing Company, 1994.

[13] Zuchdi, Darmiyati, Budiasih, Pendidikan Bahasa dan Sastra Indonesia di Kelas Rendah. Jakarta: Depdikbud, 1996. 